follows: space including ocelli, the ocelli, the eyes, the antennae, the edge of labrum, the maxillae and palpi black, head otherwise entirely reddish; spot on pleura below, spot on disc of metathorax surrounded by dusky area, and line on hind coxae above black, hind tarsi dusky, thorax and legs otherwise entirely reddish. The black ovipositor sheaths extend but a short distance beyond tip of the reddish abdomen. The head is wider than high.

Toxoneuron floridanum Ashm.-The ovipositor is fully one-half as long as the abdomen, the latter is longer and more narrow than in viator. The head is smaller and much more narrow. A female specimen from Florida received through the kindness of Mr. Ashmead.

Wm. Hampton Patton.

\section{NOTES ON THE ORTHOPTERA OF PENIKESE AND CUTTYHUNK.}

These two islands are the outermost of the Elizabeth group which separates Buzzard's Bay from Vineyard Sound, Penikese being considerably the smaller, somewhat detached, and best known from its having been the site of the marine laboratory established by Louis Agassiz. The following lists of orthoptera are but records of the specimens obtained there while on a short excursion from the Marine Biological Laboratory at Wood's Holl on Aug. 9, I893. While they cannot, of course, be considered complete, it may be worth while to record the species obtained there at this season.

The time spent on Cuttyhunk was but little over an hour - far too short to allow of even an attempt to cover the island. On Penikese, however, nearly two hours were spent, and the island quite well examined.

One noticeable feature is the apparent absence of Trimerotropis maritima from Penikese, where it was expected and sought for; this is perhaps due to the limited area of sandy beach on that island. Although not seen on Cuttyhunk I have little doubt that a longer search would have secured it.
A great difference was observed between the two islands in the abundance of individuals. On Cuttyhunk from twenty to fifty specimens could be secured as readily as one on Penikese. This was true particularly of Stenobothrus aequalis, S. maculipennis, and Melanoplus femur-rubrum, the fields fairly swarming with the young of the latter species. This difference was chiefly due, without doubt, to the large number of sheep and turkeys with which Penikese is stocked, which ramble over it at will, and by trampling and feeding upon the young locusts greatly reduce their numbers.

Nestling in the grass on Penikese were scores of young terns, some in the down and some nearly able to fly, while the air was filled with the clamor of the parent birds and elder offspring which circled overhead or perching whitened the shore.

Even here,-where they are to some extent shielded from the persecutions of their arch-destroyer, man - one was pained to witness fresh evidence of the inhuman human hand. Visitors of an earlier date had mutilated numbers of the young terns by severing the wing-tips, carrying them home as trophies, mementoes of their visit, leaving the crippled wretches to flutter helplessly about, doomed to a lingering death. Shade of Agassiz! Science is called cruel, but science was not guilty of this.

The shadow of a tern's wing is but slight, and its hue is that of the surf along the shore, yet it might well forever cloud the memory and darken the record of the heartless wretches who practised such devilish cruelty upon the helpless innocents of Penikese.

\section{CUTTYHUNK.}

\section{Acrididae.}

Stenobothrus aequalis Scudd. Abundant. " maculipennis Scudd. "

Stenobothrus curtipennis Harr. Common. Dissosteira carolina Linn. Common. 
Psinidia fenestralis Serv. Common.

Melanoplus femur-rubrum DeG. Very abundant.

Melanoplus atlanis Riley. I specimen.

\section{Locustidae.}

Orchelimum vulgare Harr. I specimen.

Xiphidium fasciatum DeG. Common.

\section{Gryllidae.}

Nemobius vittatus Harr. Common.

\section{PENIKESE.}

\section{ACrididae.}

Stenobothrus aequalis Scudd. Common. " maculipennis Scudd. "

Chortophaga viridifasciata DeG. Scarce. Dissosteira carolina Linn. Common.

Psinidia fenestralis Serv. Scarce.

Melanoplus femur-rubrum DeG. Common. Melanoplus atlanis Riley. Scarce.

\section{Locustidae.}

Xiphidium fasciatum DeG. Common.

Gryllidae.

Nemobius vittatus Harr. Common.

A. P. Morse.
Entomological Notes.

We congratulate Insect Life upon its greatly improved appearance. The last number is given up to an excellent report of the last meeting of the association of economic entomologists and about a third of it to the admirable address of the president, $\mathrm{Mr}$. L. O. Howard, which will interest all entomologists.

Parts 18 and 19 of Moore's Lepidoptera Indica treat of the Elymniinae and begin the Amathusiinae, a new subfamily of eleven genera which Moore separates from the Morphinae; the light thrown on the matter by the early stages appears to be but slight and we question if the differences pointed out are of more than tribal importance.

Mr. J. H. Emerton has recently published in the Transactions of the Connecticut Academy with four plates a list of Canadian spiders, including descriptions of new or insufficiently known forms. It comprises about one hundred species but none are included from beyond the Rocky Mountains.

To the Bihang to the Swedish academy's Handlingar for 1892 only recently received in this country, Schött contributes a paper on Californian Collembola with four excellent plates; I 8 species of II genera are discussed.

\section{A. SMITH \& SONS, 269 PEARL STREET, New York. HANUFACTURERS AND IMPORTERS OF GOODS FOR ENTOMOLOGISTS,}

Klaeger and Carlsbad Insect Pins, Setting Boards, Folding Nets, Locality and Special Labels, Forceps, Sheet Cork, Etc. Other articles are being added, Send for List.

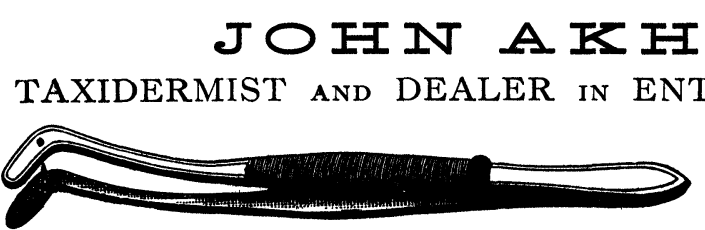

IMPROVED ENTOMOLOGICAL FORCEPS.
Fine Carlsbader Insect Pins a specialty. Price List sent on application. 78 Ashland Place,

BROOKLYN, N. Y. 

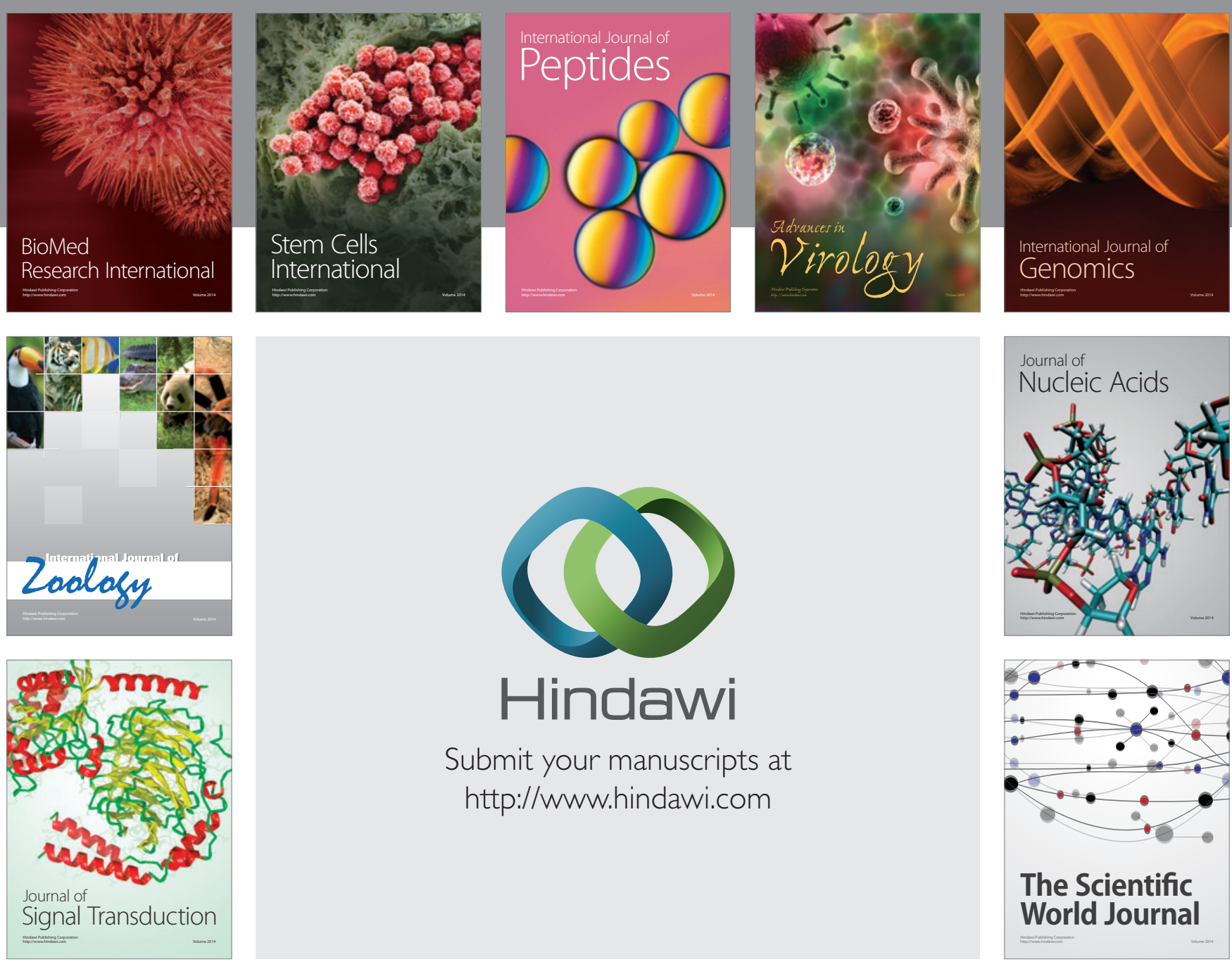

Submit your manuscripts at

http://www.hindawi.com
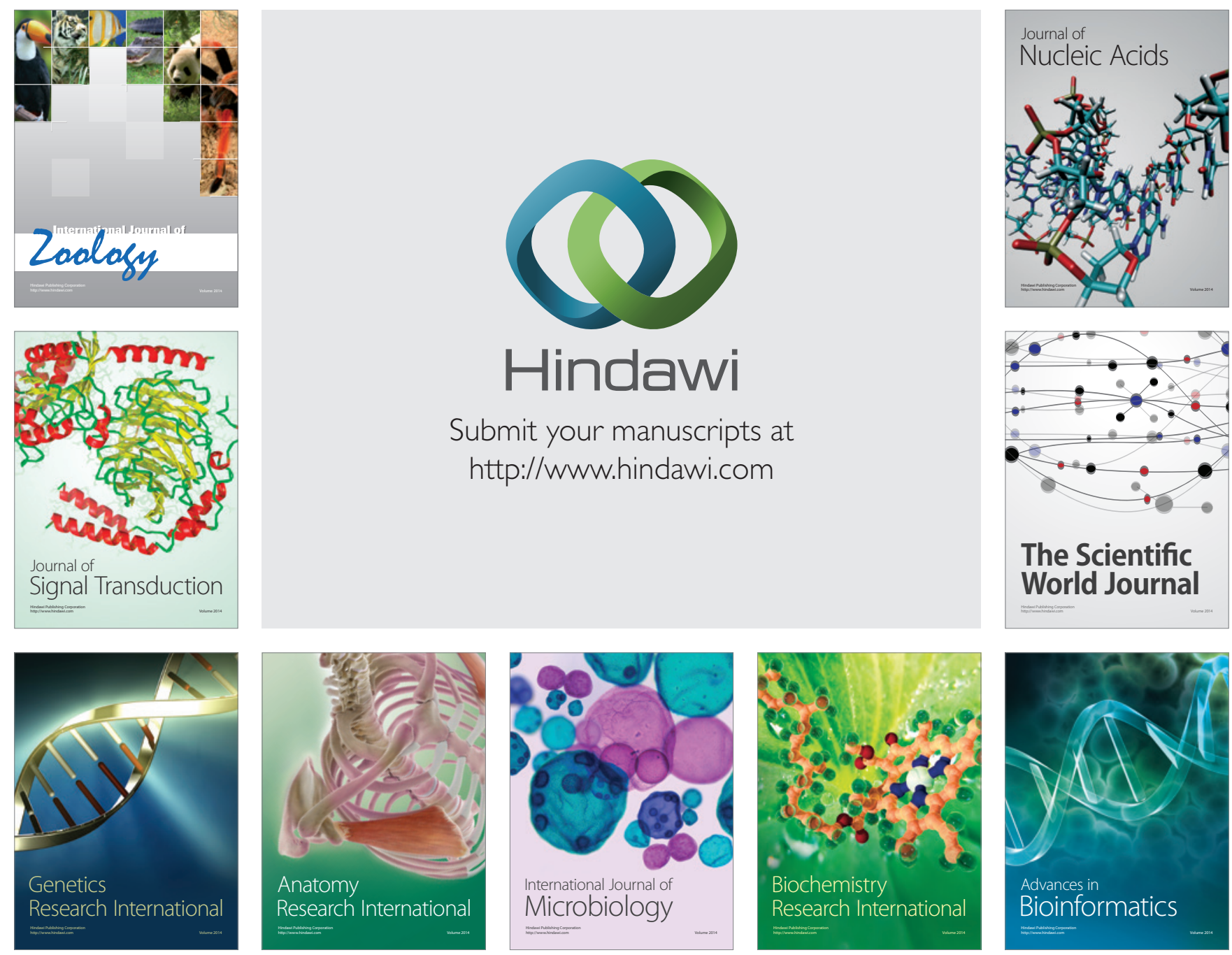

The Scientific World Journal
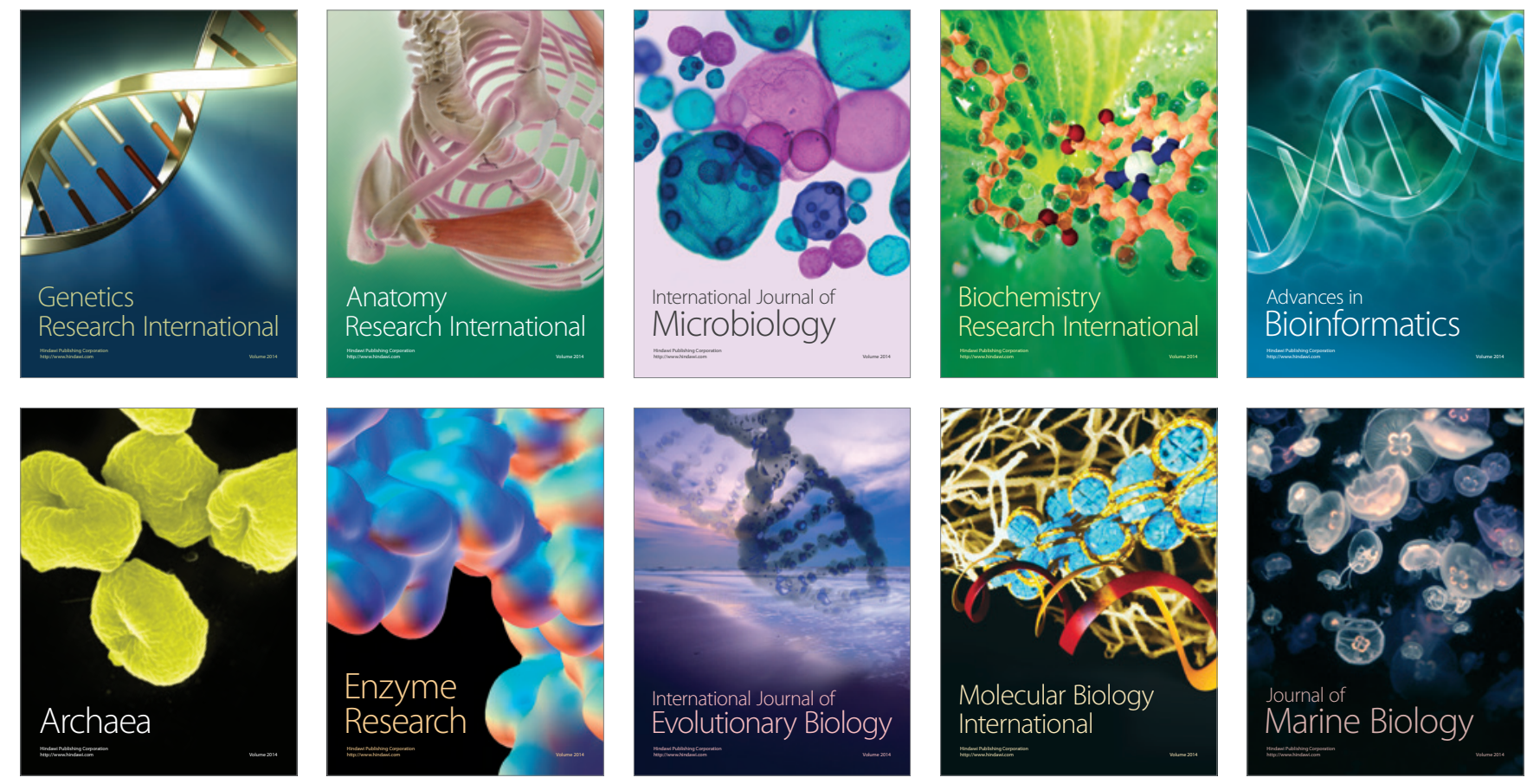